UNCERTAIN BUSINESS:

RISK, INSURANCE, AND THE LIMITS OF KNOWLEDGE

Uncertain Business explores insurance industry practices and what they tell us about risks and uncertainties in contemporary society. The core of the book is a set of unique ethnographic studies of the insurance industry. Addressing four fields of insurance - life, disability, earthquake, and terrorism - these studies reveal that a high degree of uncertainty pervades the insurance business, the very industry that is charged with transforming uncertainty into manageable risk. The authors show how scientific data on risk are often absent, inadequate, controversial, contradictory, or ignored, and how insurers often impose meaning on uncertainty through non-scientific forms of knowledge that are intuitive, emotional, aesthetic, moral, and speculative. Furthermore, the nature of uncertainty and the response to it varies substantially across the areas studied, showing how contemporary society is characterized by competing interests and forms of logic in regard to risk.

Insurers' perceptions and business decisions - with potential for huge profits as well as catastrophic losses - create crises in insurance availability and generate new forms of inequality and exclusion. Uncertain Business demonstrates that, while insurers act as a bulwark against uncertainty, they also play a key role in fostering it.

RICHARD V. ERICSON is the director of the Centre for Criminological Research at the University of Oxford and is a fellow of All Souls College.

AARON DOYLE is an assistant professor in the Department of Sociology and Anthropology at Carleton University. 
This page intentionally left blank 


\section{UNCERTAIN BUSINESS}

Risk, Insurance, and the Limits of Knowledge

Richard V. Ericson and

Aaron Doyle

UNIVERSITY OF TORONTO PRESS

Toronto Buffalo London 
www.utppublishing.com

(c) University of Toronto Press Incorporated 2004

Toronto Buffalo London

Printed in Canada

ISBN 0-8020-8759-0 (cloth)

ISBN 0-8020-8562-8 (paper)

(6)

Printed on acid-free paper

\section{National Library of Canada Cataloguing in Publication}

Ericson, Richard V., 1948-

Uncertain business : risk, insurance, and the limits of knowledge / Richard V. Ericson and Aaron Doyle.

Includes bibliographical references and index.

ISBN 0-8020-8759-0 (bound) ISBN 0-8020-8562-8 (pbk.)

1. Risk (Insurance) I. Doyle, Aaron II. Title.

HG8054.5.D69 2004 $368 \quad$ C2003-906779-3

University of Toronto Press acknowledges the financial assistance to its publishing program of the Canada Council for the Arts and the Ontario Arts Council.

University of Toronto Press acknowledges the financial support for its publishing activities of the Government of Canada through the Book Publishing Industry Development Program (BPIDP). 